\title{
Influence of Soybean (Glycine Max) Plant Extract on Corrosion of Aluminum in $1 \mathrm{M} \mathrm{HCl}$
}

\author{
Ali M. El-Azaly \\ Nile Higher Institute for Engineering and Technology, El-Mansoura, Egypt \\ E-mail: $\underline{\text { dr_alielazaly_81@yahoo.com }}$
}

doi: $10.20964 / 2019.03 .16$

Received: 17 October 2018/ Accepted: 15 December 2018 / Published: 7 February 2019

Glycine Max Extract (G.M.E.) is used as a corrosion inhibitor for aluminum alloy in $1.0 \mathrm{M} \mathrm{HCl}$ employing chemical (weight loss, WL) and electrochemical (Potentiodynamic polarization, PP, electrochemical frequency modulation, EFM and AC impedance, EIS techniques. The scanning electron microscope (SEM) was used to examine the surface morphology of Al alloy. The temperature effect on corrosion the rate in the presence of various concentrations was measured in the range of 298-318K by WL. PP curves demonstrate that G.M.E is a mixed type inhibitor. The corrosion efficiency improved by raising GM.E concentration and with improving temperature. Temkin's isotherm was established to be the best isotherm to define the adsorption of the G.M.E. on the surface of $\mathrm{Al}$ alloy. The adsorption and activation parameters had calculated and discussed.

Keywords: HCl, Aluminum alloy, Glycine Max Extract (G.M.E.), SEM. EFM, EIS

\section{$\underline{\text { FULL TEXT }}$}

(C) 2019 The Authors. Published by ESG (www.electrochemsci.org). This article is an open-access article distributed under the terms and conditions of the Creative Commons Attribution license (http://creativecommons.org/licenses/by/4.0/). 